\title{
PERKEMBANGAN ILMU ADMINISTRASI DAN FUNGSINYA UNTUK MENDUKUNG PERKEMBANGAN ILMU ADMINISTRASI
}

\author{
NURHARPANI \\ Sekolah Tinggi Ilmu Hukum Padang \\ nurharpani@gmail.com
}

\begin{abstract}
Administration etymologically comes from English, namely administration or to administear, which means to manage or to direct. Administration in the strict sense is administrative activities such as writing, writing, correspondence. administration is a collaborative activity of two or more people in achieving an activity of cooperation of two or more people in achieving a predetermined goal. Administration cannot be separated from daily life because humans are social creatures who cannot work alone and need others to achieve their goals. For this to achieve a predetermined goal, it requires the ability and motivation to encourage people and themselves to carry out and move a government organization.
\end{abstract}

Keywords: Administrative Sciences, State, Function.

Abstrak: Administrasi secara etimologi berasal dari Bahasa Inggris yaitu administration atau to administear yang berarti mengelola (to manage) atau menggerakan (to direct). Administrasi dalam arti sempit yaitu kegiatan tata usaha seperti tulis menulis, surat menyurat. administrasi merupakan suatu kegiatan kerjasama dua orang atau lebih dalam pencapaian suatu kegiatan kerjasama dua orang atau lebih dalam pencapaian suatu tujuan yang telah ditentukan sebelumnya. Administrasi tidak dapat dipisahkan dari kehidupan sehari hari karena manusia merupakan makhluksosial yang tidak bisa bekerja sendiri serta membutuhkan orang lain dalam pencapaian tujuanya. Atas hal tersebut untuk mencapai suatu tujuan yang telah ditetapkan maka diperlukan suatu kemampuan dan motivasi untuk mendorong orang-orang dan diri sendiri untuk melaksanakan dan menggerakan suatu organisasi pemerintah.

Kata Kunci: Ilmu Administrasi, Perkembangan Ilmu, Fungsi.

\section{A. Pendahuluan}

Admi nistrasi ada lah usaha dan kegi ata $n$ yang berkena an dengan penyelenggaraan kebijaksanaan untuk mencapai tujuan. Administrasi dalam arti sempit adalah kegiatan yang meliputi catat-mencatat, surat menyurat, pembukuan ringan, ketik mengetik, agenda, dan sebagainya yang bersifat teknis ketatausahaan. Administrasi dalam arti luas adalah seluruh proses kerjasama antara dua orang atau lebih dalam mencapai tujuan tertentu secara berdaya guna dan berhasil guna.

Menurut The Liang Gie (1999: 14) administrasi adalah "Segenap rangkaian penataan terhadap pekerjaan pokok yang dilakukan oleh sekelompok orang dalam kerjasama untuk mencapai tujuan tertentu." Masih dari sumber yang sama, definisi administrasi menurut Luther Gullick yaitu "Administrstion has to do with getting things done, with the accomplishment of defenid objectives."Jadi menurut Gullick, administrasi berkenaan dengan penyelesaian hal apayang hendak di kerjakan, dengan tercapainya tujuan-tujuan yang hendak ditetapkan.

Sementara itu, menurut Nawawi (1999: 1), administrasi adalah "Kegiatan atau rangkaian kegiatan sebagai proses pengendalian usaha kerjasama sekelompok manusia untuk mencapai tujuan bersama yang telah ditetapkan.” 
Menurut Siagian (2002: 2) administrasi adalah: "Keseluruhan proses kerjasama antara dua orang atau lebih yang didasarkan atas rasionalitas tertentu untuk mencapai tujuan yang telah ditentukan."

Selain itu ada juga beberapa ciri-ciri administrasi, yaitu sebagai berikut:

1. Adanya kelompok manusia yang terdiri atas 2 (dua) orang atau lebih;

2. Adanya kerjasama;

3. Adanya proses usaha;

4. Adanya bimbingan, kepemimpianan, dan pengawasan; dan

5. Adanya tujuan.

Atas perkembangan zaman pada hari ini maka sangat penting menurut penulis agar menelti tentang pentingan perkembangan ilmu administrasi negara dan fungsinya untuk mendukung perkembangan ilmu administrasi.

\section{B. Metodologi Penelitian}

Metode penelitian yang dipakai adalah metode penelitian eksploratif. Penelitian eksploratif adalah salah satu jenis penelitian sosial yang tujuannya untuk memberikan sedikit definisi atau penjelasan mengenai konsep atau pola yang digunakan dalam penelitian. Dalam penelitian ini, peneliti belum memiliki gambaran akan definisi atau konsep penelitian.

\section{Hasil dan Pembahasan}

\section{Perkembangan Ilmu Administrasi}

Menurut Pfiffner dan Presthus yang dikutip Syafei (2003: 31) memberikan penjelasan mengenai administrasi negara sebagai berikut:

a. Administrasi Negara meliputi implementasi kebijaksanaan pemerintah yang ditetapkan oleh badan-badan perwakilan politik;

b. Administrasi Negara dapat didefinisikan sebagai koordinasi usaha-usaha perorangan dan kelompok untuk melaksanakan kebijaksanaan pemerintahan. Hal ini terutama meliputi pekerjaan sehari-hari pemerintah; dan

c. Secara ringkas, Administrasi Negara adalah suatu proses yang bersangkutan dengan ke bijaksanaan-kebijaksanaan pemerintah, pengarahan kecakapan dan teknik-teknik yang tidak terhingga jumlahnya, memberikan arah dan maksud terhadap ejumlah orang.

Sedangkan menurut Chander dan Plano dalam Keban (2004: 3) mengemukakan bahwa: "Administrasi Publik adalah proses dimana sumber daya dan personel publik diorganisir dan dikoordinasikan untuk memformulasikan, mengimplementasikan, dan mengelola (manage) keputusan-keputusan dalam publik."

Sementara itu, Henry dalam Harbani Pasolong (2008: 8), mengemukakan bahwa: "Administrasi Publik adalah suatu kombinasi yang kompleks antara teori dan praktik, dengan tujuan mempromosi kan pema haman terhadap pemerintah dalam hubungannya dengan masyarakat yang di perintah, dan juga mendorong kebijakan publik agar lebih responsif terhadap kebutuhan sosial."

Administrasi publik berusaha melembagakan praktik-praktik manajemen agar sesuai dengan nilai efektivitas, efisiensi, dan pemenuhan kebutuhan masyarakat secara lebih baik. Sedangkan Waldo dalam Pasolong (2008: 8) mendefinisikan "Administrasi publik adalah manajemen dan organisasi dari manusia-manusia dan peralatannya guna mencapai tujuan pemerintah."Kesimpulan yang dapat ditarik dari beberapa pengertian 
tentang administrasi publik adalah kerjasama yang dilakukan oleh sekelompok orang atau lembaga dalam melaksanakan tugas-tugas pemerintah untuk mencapai tujuan pemerintah secara efektif dan efisien guna memenuhi kebutuhan publik.

\section{Fungsi Ilmu Administrasi}

Administrasi adalah suatu usaha dan kegiatan yang meliputi penetapan tujuan serta penetapan cara-cara penyelenggaraan pembinaan organisasi. Kegiatan administrasi memiliki fungsi penting dalam sebuah industri perkantoran atau pemerintahan. Secara umum pengertian administrasi adalah usaha atau kegiatan yang berkenaan dengan penyelenggaraan kebijaksanaan untuk mencapai tujuan. Yang termasuk dalam kegiatan administrasi antara lain adalah kegiatan mencatat, menyurat, pembukuan ringan, mengetik, membuat agenda, dan sebagainya yang bersifat teknis ketatausahaan di berbagai bidang.

Unsur-unsur yang terkait dengan administrasi antara lain yakni organisasi, manajemen, komunikasi, kepegawaian, keuangan, perbekalan, tata usaha, dan hubungan masyarakat. Kegiatan administasi pun diperlukan pada berbagai bidang, mulai dari industri, ekonomi, pemerintahan, pendidikan, dan lain-lain. Adapun tugas administrasi antara lain adalah membuat agenda perkantoran, menginput dan mengentry data, mengelola dokumen, menerima surat dan panggilan masuk, menyiapkan akomodasi kunjungan kerja, memesan persediaan alat tulis kantor, melakukan perekapan dan pengarsipan data, dan sebagainya. Tentu kegiatan administrasi ini memiliki fungsi dan tujuan tertentu. Selain tujuan umum guna memajukan kesuksesan sebuah perusahaan atau instansi, fungsi administrasi juga bisa dibagi menjadi beberapa bidang sesuai dengan manfaat yang didapatkan.

Newman, menyebut "The Work of Administration" yang dapat dibagi dalam 7 (tujuh) proses. Terdapat 7 fungsi administrasi secara umum, yakni planning, organizing, coordinating, reporting, budgeting, staffing, dan directing. Berikut ini adalah beberapa fungsi administrasi beserta penjelasan lengkapnya.

a. Perencanaan (Planning).

Salah satu fungsi administrasi yang utama adalah fungsi perencanaan atau planning. Yang dimaksud fungsi perencanaan adalah kegiatan administrasi yang meliputi pengumpulan data, pengolahan data, dan penyusunan perencanaan dalam sebuah perusahaan.

b. Pengorganisasian (Organizing).

Berikutnya ada fungsi pengorganisasian atau organizing. Administrasi memerlukan pengorganisasian yang baik di berbagai bidang. Yang dimaksud pengorganisasian adalah kegiatan menyusun dan membentuk hubunganhubungan kerja antar individu sehingga terwujud kesatuan usaha dalam mencapai tujuan perusahaan atau instansi.

c. Pengkordinasian (Coordinating)

Fungsi administrasi selanjutnya adalah fungsi pengkordinasian atau coordinating. Fungsi ini dilakukan agar kegiatan perusahaan berjalan dengan baik dan benar sehingga tidak ada kekacauan, kerusakan, atau kekosongan aktivitas dalam sebuah kesatuan usaha. Kordinasi antar divisi dan bagian juga sangat diperlukan agar saling sinkron.

d. Pelaporan (Reporting)

Fungsi pelaporan atau reporting adalah aktivitas pemantauan dan penyampain perkembangan hasil dan progress suatu kegiatan, wujudnya dengan membuat 
laporan baik lisan atau tertulis. Laporan ini akan diserahkan pada pihak terkait, biasanya dengan jabatan yang lebih tinggi, guna evaluasi kinerja ke depannya.

e. Penyusunan Anggaran (Budgeting)

Administrasi juga memiliki fungsi budgeting atau penyusunan anggaran. Hal ini meliputi kegiatan perencanaan dan pengelolaan keuangan atau anggaran dalam organisasi yang dilakukan secara berkesinambungan. Tujuannya agar semua anggaran keuangan bisa dimanfaatkan secara optimal dan efisien.

f. Penempatan (Staffing)

Fungsi administrasi juga meliputi fungsi penempatan atau staffing. Yang dimaksud fungsi penempatan adalah kegiatan yang berhubungan dengan tenaga kerja, yakni proses perekrutan, pelatihan dan pengembanga, serta pembagian tugas sesuai dengan keahlian masing-masing.

g. Pembimbingan (Directing)

Fungsi pembimbingan atau directing aktivitas berinteraksi dengan anggota organisasi dalam bentuk memberi bimbingan, saran, perintah-perintah, agar tugas dijalankan dengan baik guna mencapai tujuan yang telah ditentukan. Hal ini penting dilakukan untuk meningkatkan kinerja perusahaan.

Selajutnya administrasi berfungsi secara etimologi yang berasal dari Bahasa Inggris yaitu administration atau to administear yang berarti mengelola (to manage) atau menggerakan ( to direct). Administrasi dalam arti sempit yaitu kegiatan tata usaha seperti tulis menulis, surat menyurat.

Fungsi administrasi secara luas menurut Siagian yang dikutip oleh Pasolong dalam bukunya Teori Administrasi Publik (2011:3) mengatakan: Administrasi adalah keseluruhan proses pelaksanaan kegiatan yang dilakukan oleh dua orang atau lebih yang terlibat dalam suatu bentuk usaha kerjasama demi tercapainya tujuan yang di tentukan sebelumnya.

Gie yang dikutip oleh Pasolong dalam bukunya Teori Administrasi Publik (2011: 3) mengemukakan bahwa: Fungs administrasi adalah rangkaian kegiatan terhadap pekerjaan yang dilakukan sekelompok orang di dalam kerjasama mencapai tujuan tertentu.

Berdasarkan definisi diatas penulis dapat menyimpulkan, bahwa fungsi administrasi merupakan suatu kegiatan kerjasama dua orang atau lebih dalam pencapaian suatu kegiatan kerjasama dua orang atau lebih dalam pencapaian suatu tujuan yang telah ditentukan sebelumnya. Administrasi tidak dapat dipisahkan dari kehidupan sehari hari karena manusia merupakan makhluk sosial yang tidak bisa bekerja sendiri serta membutuhkan orang lain dalam pencapaian tujuanya.

Pengertian fungsi administrasi negara menurut Waldo dalam Kencana dalam bukunya Sistem Administrasi Negara Republik Indonesia (2003:33) mengemukakan, bahwa fungsi administrasi negara adalah manajamen dan organisasi dari manusia peralatannya guna mencapai tujuan pemerintah.

Berdasarkan pengertian diatas fungsi administrasi negara merupakan gabungan dari manajemen dan organisasi yang saling berhubungan untuk mencapai tujuan pemerintah. Siagian dalam bukumya Filsafat Administrasi ( 2008:7) mengatakan pengertian Administrasi Negara sebagai berikut: Administrasi Negara adalah keseluruhan kegiatan yang dilakukan oleh seluruh aparatur pemerintahan dari suatu Negara dalam usaha mencapai tujuan Negara. 
Dari penjelasan diatas maka dapat ditarik kesimpulan, bahwa untuk mencapai suatu tujuan yang telah ditetapkan maka diperlukan suatu kemampuan dan motivasi untuk mendorong orang-orang dan diri sendiri untuk melaksanakan dan menggerakan suatu organisasi pemerintah.

\section{Penutup}

Administrasi secara etimologi berasal dari Bahasa Inggris yaitu administration atau to administear yang berarti mengelola (to manage) atau menggerakan (to direct). Administrasi dalam arti sempit yaitu kegiatan tata usaha seperti tulis menulis, surat menyurat. administrasi merupakan suatu kegiatan kerjasama dua orang atau lebih dalam pencapaian suatu kegiatan kerjasama dua orang atau lebih dalam pencapaian suatu tujuan yang telah ditentukan sebelumnya. Administrasi tidak dapat dipisahkan dari kehidupan sehari hari karena manusia merupakan makhluksosial yang tidak bisa bekerja sendiri serta membutuhkan orang lain dalam pencapaian tujuanya. Atas hal tersebut untuk mencapai suatu tujuan yang telah ditetapkan maka diperlukan suatu kemampuan dan motivasi untuk mendorong orang-orang dan diri sendiri untuk melaksanakan dan menggerakan suatu organisasi pemerintah.

\section{Daftar Pustaka}

Anggara, Sahya, 2012. Ilmu administrasi Negara. Bandung: CV Pustaka Setia.

Atmosoedirdjo, Prajudi, Dasar-dasar Ilmu Administrasi, Seri Pustaka Ilmu Adm, Jakarta Conyers, Dana, Perencanaan Di Dunia Ketiga, Gramedia, Jakarta,1991.

Budiardjo, Miriam 2008. Dasar-Dasar Ilmu Politik. Jakarta: Gramedia.

Effendy, Onong. 1986. Human Relation \& Publik Relation. Bandung: Mandar Maju.

Irwan Soehartono, Metode Penelitian Sosial, Suatu Teknik Bidang Kesejahteraan

Sosial dan Ilmu Sosial Lainnya, Remaja Rosda Karya, Bandung, 2004.

Prawirosentono, Harbani. 2007. Teori Administrasi Publik. Bandung: Alfabeta.

Siagian. Sondang P. 2008. Filsafat Administrasi. Jakarta : PT Bumi Aksara.

Silalahi, Ulber. 2012. Metode Penelitian Sosial. Bandung : Reflika Aditama.

Silalahi, Ulber. 2011. Studi tentang Ilmu Administrasi. Bandung : Sinar Baru Algensindo.

Sugiyono. 2013. Metode Penelitian Administrasi. Bandung : Alfabeta.

Syafri, Wirman. 2012. Studi tentang Administrasi Publik. Jatinangor : Erlangga.

Thoha, Miftah. 2008. Ilmu Administrasi Publik Kontemporer. Jakarta : Kencana. 